\title{
The Effect of Acidic and Alkaline Chemical Solutions on the Behavior of Collapsible Soils
}

\author{
Mohammad Ali Khodabandeh", Saber Nokande², Ali Besharatinezhad', Behnam Sadeghi, \\ Seyed Mahdi Hosseini ${ }^{4}$
}

\footnotetext{
${ }^{1}$ Department of Engineering Geology and Geotechnics, Faculty of Civil Engineering, Budapest University of Technology and Economics, H-1111 Budapest, Műegyetem rkp. 3., Hungary

2 Department of Geotechnical Engineering, Faculty of Civil Engineering, Semnan University, 19111-35131 Semnan, Iran

${ }^{3}$ Department of Environmental Engineering, Faculty of Civil Engineering, College of Environment, Karaj 31746-1, Iran

${ }^{4}$ Department of Geotechnical Engineering, Faculty of Civil Engineering, Shahrood University of Technology, 3619995161 Shahrood, Iran

${ }^{*}$ Corresponding author, e-mail: mohammad.khodabandeh@epito.bme.hu
}

Received: 26 January 2020, Accepted: 02 May 2020, Published online: 16 July 2020

\begin{abstract}
In this research, the effect of acidic and alkaline chemical solutions on the behavior of loessial soil was investigated. To evaluate the severity of acidity and alkalinity of chemicals, two factors sulfuric acid and sodium hydroxide were used in the $\mathrm{pH}$ of 3, 5, 9, 11 . In this research, the effect of acidic and alkaline solutions on the collapse potential, shear strength parameters and unconfined compression of collapsible soils were investigated. Experimental tests results showed that acidic solutions with a low $\mathrm{pH}$ increase the collapse potential and effective cohesion of soil and decrease effective internal friction angle; on the other hand, alkaline solutions with a high $\mathrm{pH}$ decrease the collapse potential and effective cohesion of the soil and increase effective internal friction angle. The results of unconfined compression tests showed that with increasing the acidity and alkalinity in soil, the undrained strength of the soil decreased. SEM test results showed an increase in soil cavities in acidic solution while the soil cavities were fixed in alkaline solution.
\end{abstract}

\section{Keywords}

collapsible soil, collapse potential, shear strength, acid, alkali

\section{Introduction}

The occurrence of loess deposits is worldwide and can be found extensively from South America [1] to Africa [2], Europe [3], Asia [4-6], and Oceania [7]. In summary, about $10 \%$ of the Earth's surface has been covered by this special type of geomaterial [8]. The foundations constructed on collapsible soils might settle due to the saturation of the soils for various reasons such as water pipe failure, sewage leakage, drainage of reservoirs or pools, rising groundwater level, leaks of industrial effluents and chemicals, etc. [9]. Several studies have been conducted on the effects of leachate and chemicals solutions on the behavior of granular and fine-grained soils. A point is that in all previous research, the results were different, for each type of soil and no coherence was observed between the outcomes of the studies. Therefore, further consideration is required to understand the behavior of collapsible soils when they are subjected to chemical attacks.
The previous works were focused on soil type, stress condition, permeability, and the acid and alkali type. Kaya and Fang [10] studied the effect of organic fluids on kaolinite and bentonite soils and concluded that when void space in soil is replaced with organic liquids, soil engineering properties, such as hydraulic conductivity and stress-strain behavior were significantly altered.

Ratnaweera and Meegoda [11] examined the unconfined compressive strength of fine-grained soils contaminated with various types of chemicals (Glycerol, propanol and acetone). The results showed a decrease in shear strength and stress-strain behavior of contaminated soils. This decrease in shear strength is attributed to the physico-chemical effects created by the decrease in dielectric constant and the mechanical interactions induced by high pore fluid viscosities. In another study by Wang and Siu [12], the structural and mechanical properties 
of kaolinite when faced with different $\mathrm{pH}$ levels were investigated. They found that acidic liquid increased the compression of soil due to the reduction of void space. Sridharan et al. [13] stated that the shear strength behavior of kaolinite under the influence of organic fluids differed greatly in comparison with montmorillonite. It is notable that, while the undrained shear strength value increased in kaolinite, it decreased in montmorillonite.

Moavenian and Yasrobi [14] examined the effect of organic liquids on volume change behavior of clayey soils. Results showed that pure organic chemicals caused less heaving in comparison with distilled water. Also, contaminated soil's plasticity reduced, and organic fluid caused osmotic consolidation in soil. Tang et al. [15] found that anionic surfactant would weaken the loess properties, which could lead to a decline in cohesion, improved compressibility, and decreased permeability, but can reduce the collapsibility of loess.

Olgun and Yildiz [16] observed that with increasing the acetic acid $(20 \%, 40 \%, 60 \%, 80 \%)$ in clay soils, the cohesion of soils increased. Also, they observed that the liquid limit and plasticity index have been significantly decreased in montmorillonite due to the collapse of the diffuse double layer and in kaolinite increased slightly due to gelification. Spagnoli et al. [17] represented that when the $\mathrm{pH}$ value of solutions changes, the undrained shear strength of the kaolinite and montmorillonite mixed clay increases. Thus, it can be noted that the chemical property of the pore water is an important factor in the shear strength of soil. In another study, Yang et al. [18] concluded that the acidic conditions caused the erosion of cementitious soils, while alkaline conditions had less effect on soil properties. They observed that in acidic and alkaline conditions the unconfined compressive strength (UCS) of cementitious soils decreased (around $30 \%$ of initial strength).

Rahman and Nahar [19] investigated the effect of $\mathrm{pH}$ on shear strength behavior of granular soil and concluded that the shear strength increase with the increase of $\mathrm{pH}$ values of soil. Reddy et al. [20] have examined the effect of acidic and alkaline fluids on expansive soil fluctuation behavior. The results showed that swelling of soil contaminated with sodium hydroxide first increased in lower concentrations and then decreased with increasing concentration; however, the swelling of soil contaminated with sulfuric acid decreased at low concentration, and then increased with increasing concentration of the sulfuric acid solution.
Li et al. [21] have investigated the effect of alkaline leachate on the mechanical properties of stiff clays (CL) and they observed a decrease in cohesion and an increase in the internal friction angle with increasing the alkaline leachate $(\mathrm{pH}>7)$ in the soil. Sunil et al. [22] have investigated the effect of alkaline leachate on SC coarse-grained soils and they found an increase in cohesion and a decrease in the internal friction angle of the soil with an increase in alkalinity of the soil.

Overall, the acidic and alkaline chemical solutions could significantly change the physical and mechanical properties of the soils. Although most of the previous studies have focused on clay and sandy soils, fewer studies were conducted on the problematic soils including collapsible soil. In this study, the changes in physical and mechanical properties of collapsible soils when they contaminated with chemicals at a different range of $\mathrm{pH}$ levels were investigated.

\section{Materials}

\subsection{Soil}

The soil used in this study was loess which was taken from Kalaleh area in Golestan province, Iran, where sampling

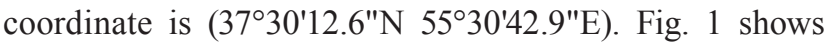
the location of the sampling site. Undisturbed soil samples were taken in $30 \times 30 \times 30 \mathrm{~cm}^{3}$ boxes from $1 \mathrm{~m}$ below the ground surface to prevent the upper organic soil layer and grass roots. Immediately after sampling, the boxes were isolated with paraffin to prevent the loss of moisture. The clay soil was classified as CL according to the unified soil classification system (USCS) category. The particle size distribution of the soil is presented in Fig. 2.

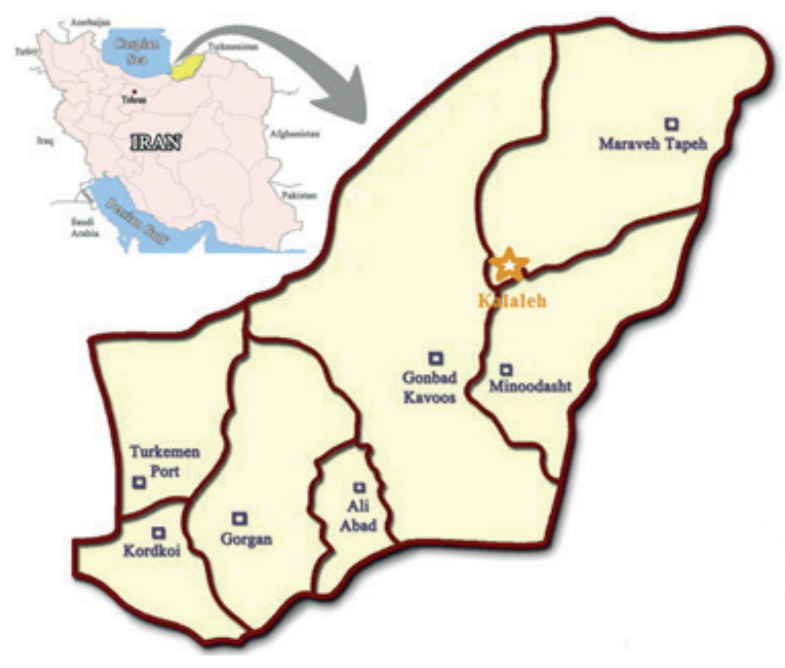

Fig. 1 The location of the sampling site 


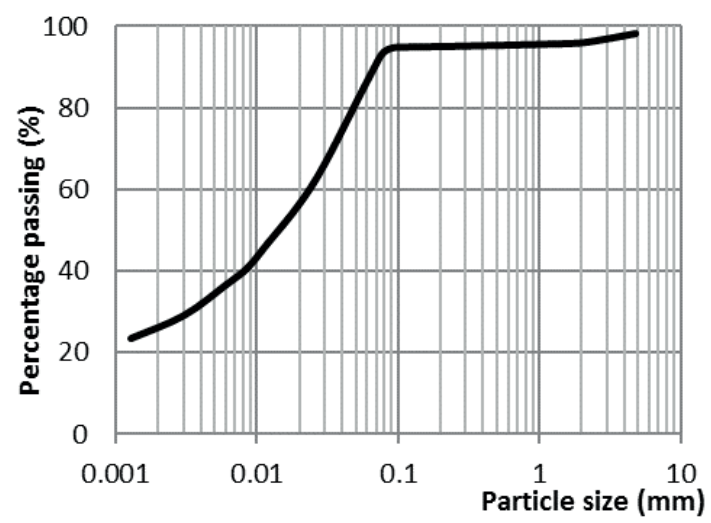

Fig. 2 Grain size distributions of loess soil samples

The Atterberg limit test has been carried out on the soil according to the ASTM D4318-87 standard, and the results of liquid limit and plasticity limits are reported in Table 1. The specific gravity (Gs) and the $\mathrm{pH}$ of the soil were determined according to the ASTM 854-92 standard and ASTM D4972-01 standard, respectively. The result is shown in Table 1.

\subsection{Chemicals}

In order to simulate the effect of chemical solutions on the behavior of collapsible soils, sulfuric acid and sodium hydroxide were used to prepare solutions with different $\mathrm{pH}$ levels. Note that the required amount of sulfuric acid and sodium hydroxide was chosen to reach the $\mathrm{pH}$ levels of $3,5,7,9$ and 11 to simulate the most critical condition. The purity of sulfuric acid and sodium hydroxides were 98 $\%$ and $95-98 \%$, respectively.

\section{Laboratory program}

\subsection{Sample preparation}

Tests were conducted in undisturbed and remolded conditions. Each type of sample was used for a specific purpose; undisturbed samples were used to test soils in their natural skeleton, while remolded samples were used to make homogeneous mixtures of soil and contamination.

Table 1 Soil property and value

\begin{tabular}{lc}
\hline Soil & Collapsible soil \\
\hline USCS & CL \\
pH & 7.9 \\
GS & 2.67 \\
Natural water Content (\%) & 3.57 \\
Vdry (gr/cm3) & 1.42 \\
LL (\%) & 29 \\
PL (\%) & 21 \\
PI (\%) & 8 \\
\hline
\end{tabular}

Remolded samples were made with the same void ratio and unit weight as those of undisturbed samples. To construct remolded samples, portions of the box $\left(30 \times 30 \times 30 \mathrm{~cm}^{3}\right)$ samples were completely crushed, dried in the oven, passed from a No. 40 sieve, and then uniformly mixed with de-aired distilled water at an average moisture content of $3.5 \%$ (almost equal to the mean field natural value). Then, for a more uniform distribution of water content the mix was placed in a sealed plastic bag for 48 hours. After that, the soil was used for different tests. Remolded samples were completely saturated with chemical solutions with different $\mathrm{pH}$ level ranges to assess contamination in the saturated state to determine the collapsibility and shear strength parameters of collapsible soils. Also, other remolded specimens were contaminated with chemical solutions at 5,10 and $15 \%$ by weight of the dry soil samples for the UCS test. This form of sampling was chosen because there is no possibility to saturate the samples during the UCS test. Then, the samples were placed in insulated plastic containers for 20 days for aging, achieving an equilibrium state and allowing possible reactions between soil and chemicals.

\subsection{Collapse test}

The measurement of the collapse potential of soil was conducted according to the ASTM D5333 standard. The collapse test is similar to the consolidation test since the specimen is internally consolidated. After placing the sample in the device and closing the measuring equipment, the initial stress of $5 \mathrm{kPa}$ was applied to the sample. After applying initial stress, different levels of stress including 12.5 , $25,50,100,200 \mathrm{kPa}$ were applied to the samples and the deformation (settlement) of soil was measured in each step. Then the sample was wetted $1 \mathrm{hr}$ after applying $200 \mathrm{kPa}$ and the loading last for up to 24 hours in saturated condition and the settlement was monitored. It should be noted that if the fluid is applied from the bottom of the sample, all the trap air comes out and the sample reaches to fully saturated condition. According to the test, the index of collapse which indicates the settlement of sample under the stress of $200 \mathrm{kPa}$, is obtained from Eq. (1) [23].

$I_{C}=\left(d_{f}-d_{i}\right) / h_{0} \times 100$

$I_{C}:$ the potential collapse

$d_{f}$ : measurement the settlement after saturation

$d_{i}$ : measurement the settlement before saturation

$h_{0}$ : initial height of the sample 


\subsection{Setup for collapse test}

The plan of the test is as follows:

First, the collapse test was conducted on undisturbed soils to measure the amount of collapse. Then, the collapse test was performed on the remolded samples with the same density and moisture of the field. In this case, the chemical solutions which were made in the laboratory were used as fluids instead of water to determine the effect of $\mathrm{pH}$ on the collapse potential of soil.

It should be noted that the remolded samples were used for the study since the undisturbed samples have different initial moisture, dry density, and void index; therefore, it was hard to investigate the effect of $\mathrm{pH}$ on the collapse potential of soil when the others parameters are not same. Thus, all the other parameters affecting the collapse rate were kept the same. Table 2 presents the program of collapse tests.

\subsection{Direct shear test}

In this study, the direct shear tests were performed on soil samples under drained conditions according to ASTM D3080/D 3080M [24]. The straight-sectional cube with a dimension of $60 \times 60 \times 60 \mathrm{~mm}$ was used to perform a direct shear test. The speed of upper shear box displacement was set at $0.048 \mathrm{~mm} / \mathrm{min}$ for all the soil samples. The plan of the direct shear test is as follows:

First, the direct shear test was performed on the remolded soil with density and moisture of the field to estimate the shear strength of the soil; In this case, the samples were directly subjected to distilled water at the $\mathrm{pH}$ of 7 to saturate. Then, the direct shear test was performed on the remolded soil with a density and moisture of the field in condition that the saturation was happened by the chemical solution (acid sulfuric and water, sodium

Table 2 The program of collapse tests

\begin{tabular}{|c|c|c|c|}
\hline $\begin{array}{l}\text { Method } \\
\text { Used }\end{array}$ & $\begin{array}{l}\text { Sample } \\
\text { condition }\end{array}$ & Saturating fluid & $\begin{array}{c}\text { Chemical solution } \\
\text { content }(\%)\end{array}$ \\
\hline \multirow{6}{*}{ 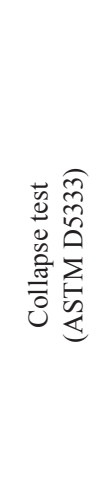 } & undisturbed & $\begin{array}{l}\text { Distilled water } \\
\qquad(\mathrm{pH}=7)\end{array}$ & 100 \\
\hline & remolded & $\begin{array}{l}\text { Distilled water } \\
\qquad(\mathrm{pH}=7)\end{array}$ & 100 \\
\hline & remolded & $\begin{array}{l}\text { Acid sulfuric and } \\
\text { water }(\mathrm{pH}=3)\end{array}$ & 100 \\
\hline & remolded & $\begin{array}{l}\text { Acid sulfuric and } \\
\text { water }(\mathrm{pH}=5)\end{array}$ & 100 \\
\hline & remolded & $\begin{array}{l}\text { Sodium hydroxide } \\
\text { and water }(\mathrm{pH}=9)\end{array}$ & 100 \\
\hline & remolded & $\begin{array}{l}\text { Sodium hydroxide } \\
\text { and water }(\mathrm{pH}=11)\end{array}$ & 100 \\
\hline
\end{tabular}

hydroxide and water); In this case, to saturate the sample, the chemical solutions which were made in the laboratory were used at different $\mathrm{pH}$ levels instead of water to determine the effect of acidic and alkaline solutions on the shear strength parameters of soils. Table 3 presents the program of direct shear tests.

\subsection{Unconfined compression test}

To evaluate the effect of acidic and alkaline chemical solutions on the undrained shear strength and stress-strain characteristics of collapsible soils, unconfined compression tests were performed according to ASTM-D2166 standard [25] on the clean soil samples and also on the contaminated soil. The procedure was as follows: the soil samples were contaminated by acidic $(\mathrm{pH}=3)$ and alkaline $(\mathrm{pH}=11)$ solutions at the $5 \%, 10 \%$ and $15 \%$ (by weight $\%$ ), then after the treatment, unconfined compression test was conducted on the clean and contaminated soil samples in unsaturated state. Table 4 presents the program of unconfined compression strength tests.

Table 3 The program of direct shear tests

\begin{tabular}{lccc}
\hline $\begin{array}{l}\text { Method } \\
\text { Used }\end{array}$ & $\begin{array}{c}\text { Sample } \\
\text { condition }\end{array}$ & Saturating fluid & $\begin{array}{c}\text { Chemical solution } \\
\text { content }(\%)\end{array}$ \\
\hline remolded & $\begin{array}{c}\text { Acid sulfuric and } \\
\text { water }(\mathrm{pH}=3)\end{array}$ & 100 \\
& remolded & $\begin{array}{c}\text { Acid sulfuric and } \\
\text { water }(\mathrm{pH}=5)\end{array}$ & 100 \\
$\begin{array}{l}\text { Direct shear } \\
\text { test } \\
\text { (ASTM D) }\end{array}$ & remolded & $\begin{array}{c}\text { Distilled water } \\
(\mathrm{pH}=7)\end{array}$ & 100 \\
& remolded & $\begin{array}{c}\text { Sodium hydroxide } \\
\text { and water }(\mathrm{pH}=9)\end{array}$ & 100 \\
& remolded & $\begin{array}{c}\text { Sodium hydroxide } \\
\text { and water }(\mathrm{pH}=11)\end{array}$ & 100 \\
\hline
\end{tabular}

Table 4 The program of unconfined compression strength tests

\begin{tabular}{|c|c|c|c|}
\hline $\begin{array}{l}\text { Method } \\
\text { Used }\end{array}$ & $\begin{array}{l}\text { Sample } \\
\text { condition }\end{array}$ & Contaminant type & $\begin{array}{c}\text { Chemical solution } \\
\text { content }(\%)\end{array}$ \\
\hline \multirow{7}{*}{$\begin{array}{l}\text { Unconfined } \\
\text { compression } \\
\text { strength }\end{array}$} & Remolded & Clean & 0 \\
\hline & Remolded & $\begin{array}{l}\text { Acid sulfuric and } \\
\text { water }(\mathrm{pH}=3)\end{array}$ & 5 \\
\hline & Remolded & $\begin{array}{l}\text { Acid sulfuric and } \\
\text { water }(\mathrm{pH}=3)\end{array}$ & 10 \\
\hline & Remolded & $\begin{array}{l}\text { Acid sulfuric and } \\
\text { water }(\mathrm{pH}=3)\end{array}$ & 15 \\
\hline & Remolded & $\begin{array}{l}\text { Sodium hydroxide } \\
\text { and water }(\mathrm{pH}=11)\end{array}$ & 5 \\
\hline & Remolded & $\begin{array}{l}\text { Sodium hydroxide } \\
\text { and water }(\mathrm{pH}=11)\end{array}$ & 10 \\
\hline & Remolded & $\begin{array}{l}\text { Sodium hydroxide } \\
\text { and water }(\mathrm{pH}=11)\end{array}$ & 15 \\
\hline
\end{tabular}




\section{Results}

4.1 The results of collapse potential of undisturbed and remolded soils when saturated with water

To prove the collapse potential of soil, the collapse experiment was carried out to determine the collapse potential on remolded and undisturbed soils when both samples were saturated with water. The test results are presented in Table 5. According to the results, the tested soil is placed in a highly collapsible category based on ASTM D5333 standard.

As can be seen in Table 5, the remolded samples condition decreased the collapse rate, with the average collapse reduced from $17.85 \%$ to $11.67 \%$ for the remolded sample. The reason for this reduction can be attributed to the void space and changes in soil structure which play a very effective role in the collapse condition. As a result, it can be concluded that the disturb condition would reduce the void ratio and thus decrease the collapse potential of soil. Fig. 3 shows the comparison between the collapse behavior of both remolded and undisturbed samples.

As shown in Fig. 3, the collapse potential of soil reduced by $6 \%$ in remolded samples, but still, the soil is in severe collapse condition. Fig. 4 shows the macroscopic and microscopic pores of the collapsible soil structure. Although disturbance may break down the macroscopic and larger pores, but there are also smaller pores that remolded effort can't break down them and remained collapse potential is caused by these pores.

\subsection{The results of collapse potential of soil when} saturated with chemical solutions at different $\mathrm{pH}$ levels It was observed in Fig. 5 that decreasing the $\mathrm{pH}$ of the solution (acidic condition) caused an increase in soil collapse. The amount of soil collapse was $11.67 \%, 14.53 \%$ and $16.75 \%$ at the $\mathrm{pH}$ of 7,5 and 3 respectively, which proved the acidic condition increased the collapse potential of soil. Moreover, it can be seen that the amount of soil collapse was reduced from $11.67 \%$ to $9.63 \%$ when the $\mathrm{pH}$ of the solution increased from 7 to 11 , respectively.

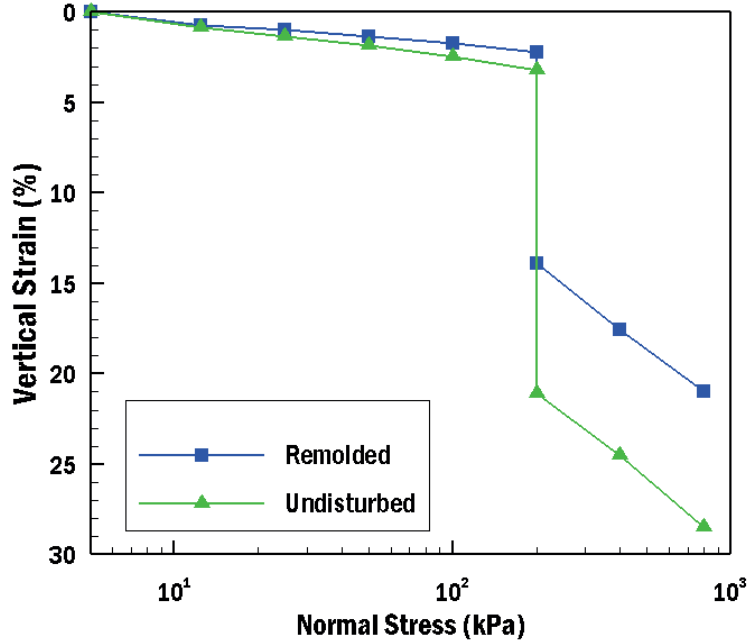

Fig. 3 Comparison of remolded and undisturbed samples collapse behavior
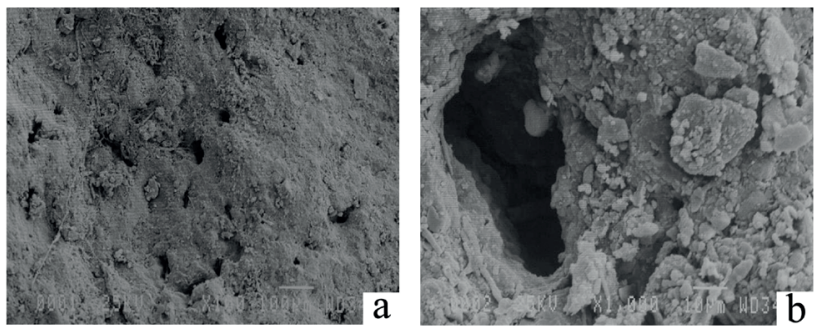

Fig. 4 SEM images of undisturbed loess soil: a) macroscopic image at 100x magnification, and b) microscopic image at 1000x magnification [26]

According to Fig. 5, it can be seen that the changes in the collapse potential of soil in acidic conditions $(\mathrm{pH}<7)$ were more variable compared to alkaline conditions $(\mathrm{pH}>7)$. In other words, in the most acidic condition, an increase of $5.08 \%$ of the collapse was observed; however, in alkaline condition, only $2.04 \%$ of change was observed in the collapse potential of soil.

When sulfuric acid is diluted in water, its breakdown occurs in two steps which are presented in Eqs. (2) and (3):

$$
\begin{aligned}
& \mathrm{H}_{2} \mathrm{SO}_{4}+\mathrm{H}_{2} \mathrm{O} \rightarrow \mathrm{H}_{3} \mathrm{O}^{+}+\mathrm{HSO}_{4}, \\
& \mathrm{HSO}_{4}{ }^{-}+\mathrm{H}_{2} \mathrm{O} \rightarrow \mathrm{H}_{3} \mathrm{O}^{+}+\mathrm{SO}_{4}{ }^{-2} .
\end{aligned}
$$

\begin{tabular}{|c|c|c|c|c|c|c|c|c|c|}
\hline $\begin{array}{l}\text { Sample } \\
\text { conditions }\end{array}$ & sample & $\begin{array}{l}\text { Initial void } \\
\text { index }\end{array}$ & $\begin{array}{l}\text { Final void } \\
\text { index }\end{array}$ & $\begin{array}{c}\text { Initial } \\
\text { Moisture (\%) }\end{array}$ & $\begin{array}{c}\text { Final } \\
\text { Moisture (\%) }\end{array}$ & $\gamma_{d}\left(\mathrm{~g} / \mathrm{cm}^{3}\right)$ & $\begin{array}{l}\text { Rate of } \\
\text { collapse }\end{array}$ & $\begin{array}{l}\text { Average of the } \\
\text { rate of collapse }\end{array}$ & $\begin{array}{l}\text { Collapse } \\
\text { condition }\end{array}$ \\
\hline \multirow{3}{*}{ Undisturbed } & 1 & 1.05 & 0.37 & 3.72 & 18.87 & 1.3 & 19.58 & \multirow{3}{*}{17.85} & \multirow{3}{*}{ severe } \\
\hline & 2 & 0.89 & 0.33 & 3.79 & 18.74 & 1.41 & 17.94 & & \\
\hline & 3 & 0.74 & 0.26 & 3.14 & 16.29 & 1.53 & 16.04 & & \\
\hline \multirow{3}{*}{ Remolded } & 4 & 0.9 & 0.48 & 3.5 & 20.43 & 1.42 & 12.5 & \multirow{3}{*}{11.67} & \multirow{3}{*}{ severe } \\
\hline & 5 & 0.9 & 0.52 & 3.5 & 21.1 & 1.42 & 11.9 & & \\
\hline & 6 & 0.9 & 0.49 & 3.5 & 20.75 & 1.42 & 10.63 & & \\
\hline
\end{tabular}

Table 5 Results of collapse tests for undisturbed and remolded soils in saturated condition with water 


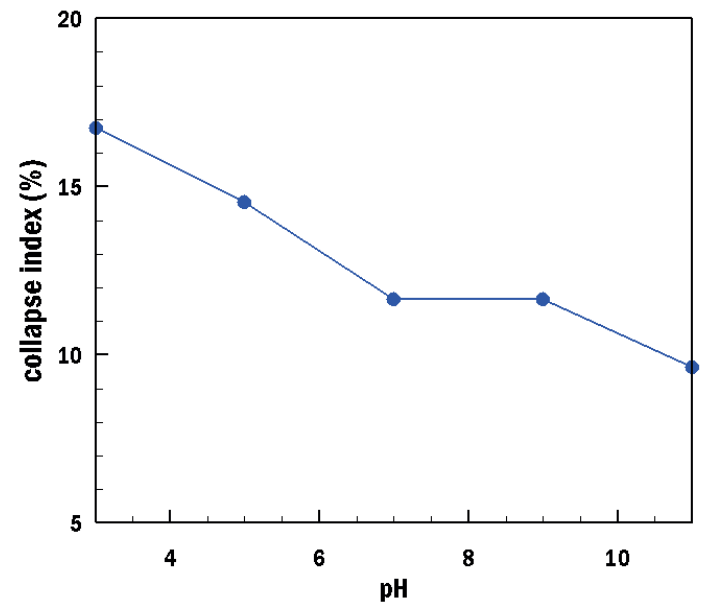

Fig. 5 Comparison of the behavior of collapse potential vs $\mathrm{pH}$

First, sulfuric acid in combination with water decomposed to hydronium $\left(\mathrm{H}_{3} \mathrm{O}\right)$ and ion sulfate. Hydronium ions, due to its smaller size and ionic potential (hydrated cation charge), could easily penetrates mineral crystals and leads to a decrease in the hydrogen bond between the successive units of kaolinite. Hydrogen ions can eliminate iron in kaolinite networks (structure) and can create a new mineral by combining anions $\left(\mathrm{SO}_{4}{ }^{-2}\right)$. However, $\mathrm{SO}_{4}^{-2}$ anion remains in action and acts as an anion for cations. Therefore, these reactions cause significant changes in soil microstructure. Moreover, $\mathrm{H}_{3} \mathrm{O}^{+}$caused changes in the cation exchange in clay components, which leads to a change in the mineral content and soil microstructure [27].

Therefore, the reason for the increase in collapse soil in the acid-saturated state could be related to the destruction of the clay microstructure due to the interaction of clay minerals when faced with acidic fluid. The acidic fluids caused the soil to collapse rapidly by separating the anions and cations in clay interlayer. When the soil is contaminated by acidic fluid, in the liquid phase a large proportion of the salt is dissolving and solid-phase property of the soil changed and it caused the reduction in soil strength and therefore the collapse happened.

The reason for the decrease in soil collapse at alkaline conditions $(\mathrm{pH}>7)$ is related to the reduced solubility of ions. Therefore, most ions are remaining in solid form in soil and only a small change in collapse potential occurred. Fig. 6 shows the collapse potential of soil in a saturated state with different chemical solutions.

\subsection{Results of the direct shear test when samples were saturated with chemical solutions at different $\mathrm{pH}$ levels}

To determine the effective cohesion and effective internal friction angle parameters of soil, the results of the direct

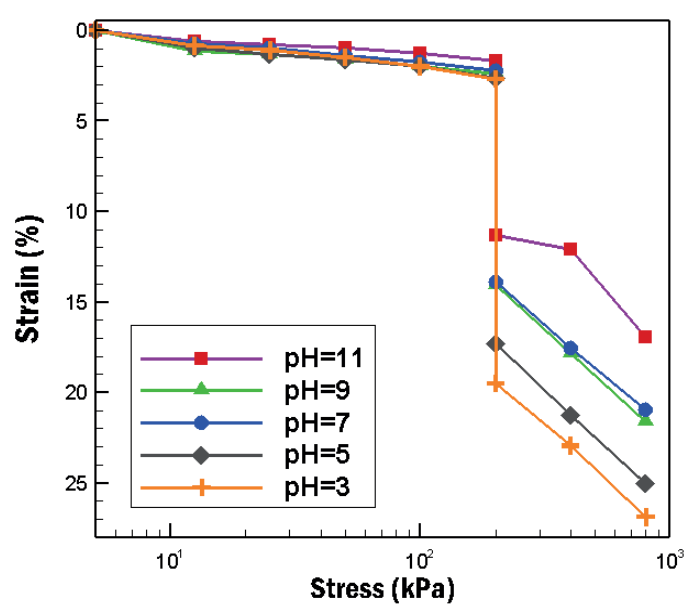

Fig. 6 Comparison of collapse potential in saturated conditions with different $\mathrm{pH}$ values

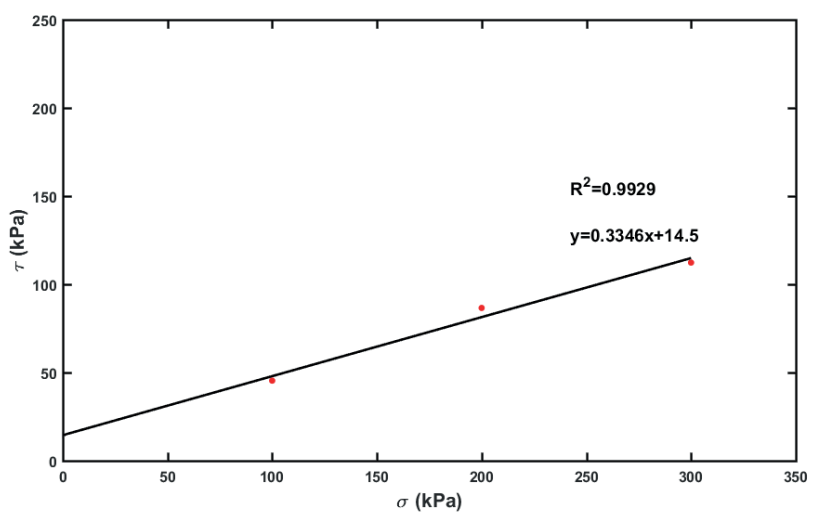

Fig. 7 Soil Failure envelope after saturation with water $(\mathrm{pH}=7)$

shear test (vertical stress-shear stress) were shown in Fig. 7. It should be noted that the direct shear test was carried out on soil samples after the collapse condition happens and each test was performed in three repetitions and the average of them was presented.

As shown in Fig. 7, the effective cohesion parameter and effective internal friction angle for soil saturated with water $(\mathrm{pH}=7)$ were $14.5 \mathrm{kPa}$ and $18.5^{\circ}$, respectively.

The tests were performed on the remolded samples which were saturated with chemical solutions at different $\mathrm{pH}$ levels. The results of the direct shear test on the saturated samples are shown in Table 6.

Table 6 Direct shear test results under saturated conditions with different $\mathrm{pH}$ values

\begin{tabular}{lcc}
\hline $\mathrm{pH}$ & $\mathrm{C}^{\prime}(\mathrm{kPa})$ & $\varnothing^{\prime}\left({ }^{\circ}\right)$ \\
\hline 3 & 35.33 & 16.04 \\
5 & 30.86 & 17.25 \\
7 & 14.5 & 18.5 \\
9 & 11.34 & 20.53 \\
11 & 8.16 & 21.89 \\
\hline
\end{tabular}


It can be seen in Table 6 that the effective cohesion parameter of the soil increased $144 \%$ when the $\mathrm{pH}$ levels decreased from 7 to 3 and decreased $78 \%$ when the alkaline solution is used as the fluid. In conclusion, the range of effective cohesion changes in acidic states were much greater than that of alkaline state. Compared to the previous research, an increase in the cohesion of clayey soil in acidic condition was observed by Olgun and Yildiz [16], In addition $\mathrm{Li}$ et al. [21] reported a decrease in the cohesion of clayey soil in alkaline condition, which are similar to the results of the present study.

Therefore, it is observed that effective internal friction angle of the soil increased by increasing the $\mathrm{pH}$ levels and it was $16.04^{\circ}$ and $21.89^{\circ}$ when the $\mathrm{pH}$ level of the soil was 3 and 11, respectively. Also, it was proved that in acidic condition, the effective internal friction angle of the soil was in lowest. Fig. 8 shows the comparison pattern of ruptures for samples when saturated with different $\mathrm{pH}$ levels. To investigate the soil behavior better, normal tension has extended up to $1000 \mathrm{kPa}$ in soil failure envelope.

Since in the direct shear test, the soil is under vertical stress, it was observed that in the acidic condition, the collapse of the soil increased. At the acidic condition, the soil became denser and showed higher shear strength. Therefore, when the shear strength is high, the effective cohesion of the soil is high as well.

Similarly, according to Fig. 5 and the results of Table 6, it can be concluded that by increasing the $\mathrm{pH}$ of the solution, the settlement of the test soil decreased and therefore required a less horizontal force for the initial shearing. Note that with decreasing shear force, the rupture

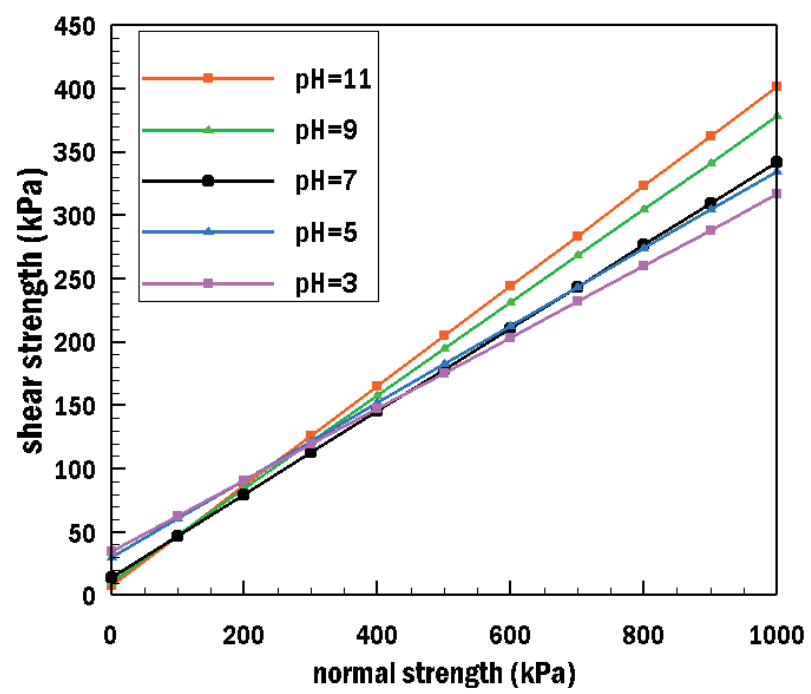

Fig. 8 Failure envelope graphs under saturated conditions with different $\mathrm{pH}$ values diagram is placed at a lower altitude and effective cohesion decreased. Fig. 9 shows the percentage of soil shear strength variations in each $\mathrm{pH}$ compared to the shear strength of the soil at $\mathrm{pH}=7$.

As shown in Fig. 9, at lower $\mathrm{pH}$, the shear strength of the soil increased due to an increase in effective cohesion. For example, at $\mathrm{pH}=3$, at first $144 \%$ increase in shear strength at $\sigma^{\prime}=0 \mathrm{kPa}$ and $34 \%$ increase in shear strength at $\sigma^{\prime}=$ $1 \mathrm{kPa}$ was observed. But at the higher vertical stress, the shear strength of the soil decreased. Therefore, it can be concluded that due to the high values of vertical stress, by decreasing the $\mathrm{pH}$ of the solution and becoming more acidic, the effective internal friction angle decreased. According to Mohr Coulomb equation, the shear strength of the soil decreases even with increasing effective cohesion.

Similarly, at high $\mathrm{pH}$, first, the shear strength of the soil is reduced then with increasing vertical stress, the shear strength of the soil increased, which increased the effective internal friction angle at high $\mathrm{pH}$. According to the Mohr Coulomb stress equation, the increase in shear strength of the soil might happen even with decreasing effective cohesion. For example, at $\mathrm{pH}=11$ at first, $44 \%$ decrease in shear strength at $\sigma^{\prime}=0$ was observed, but the vertical stress increased as the shear strength of the soil increased.

\subsection{The results of unconfined compression test}

Figs. 10 and 11 show the undrained shear strength versus the axial strain for the contaminated soil samples which were contaminated at the different ratios of acidity $(\mathrm{pH}=3)$ and alkalinity $(\mathrm{pH}=11)$. It is observed that with increasing the acidity and alkalinity of the chemical

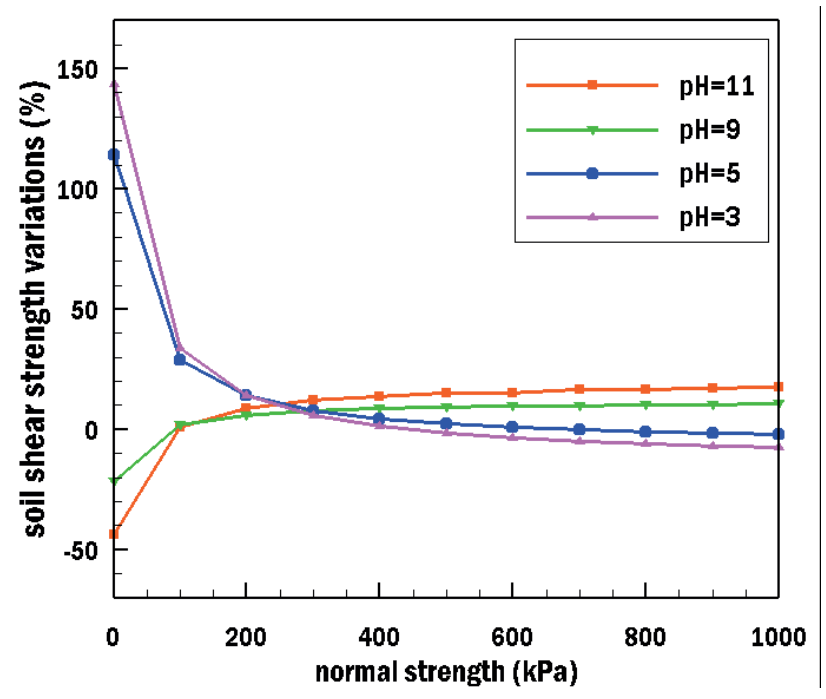

Fig. 9 Percentage of soil shear strength variations in each $\mathrm{pH}$ compared to the shear strength of the soil at $\mathrm{pH}=7$ 


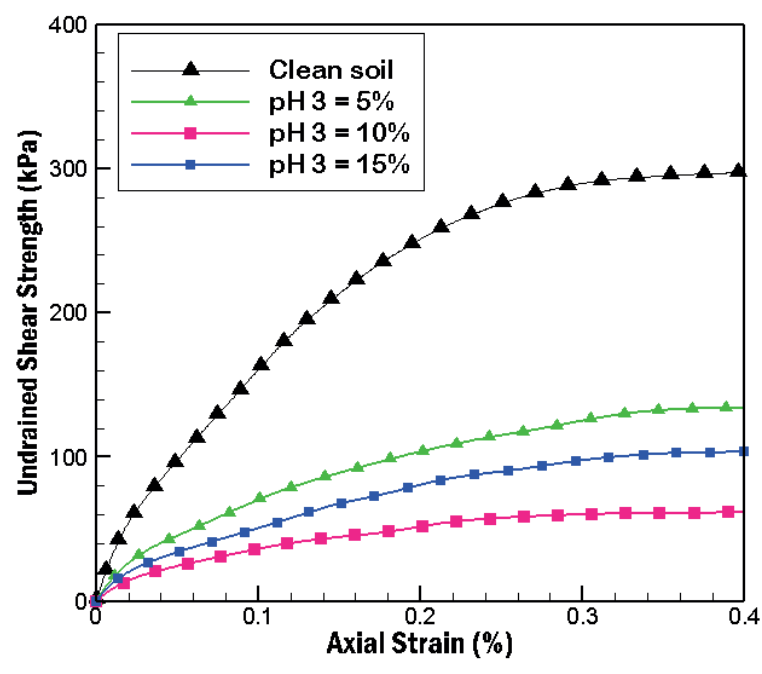

Fig. 10 the influence of acidic solution on the undrained shear strength of collapsible soil

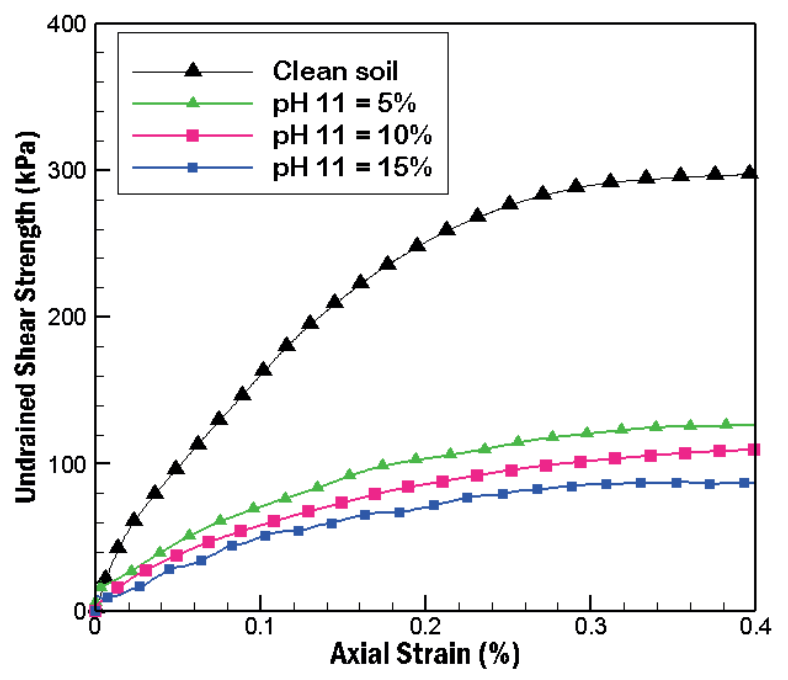

Fig. 11 The influence of alkaline solution on the undrained shear strength of collapsible soil

solution, the undrained shear strength of the contaminated soils decreased, which led to a decrease in strength as the percentage of chemical solution in the soil increased. The results are similar to previous study carried out by Yang et al. [18] concluding that in acidic and alkaline conditions, the unconfined compressive strength (UCS) of cementitious soils decreased.

\subsection{X-ray diffraction (XRD) results}

To better understand the effect of acidic and alkaline solutions on soil minerals, the XRD test was carried out on three soil samples (1) soil without contamination at $\mathrm{pH}=7$, (2) contaminated soil with chemical solution at $\mathrm{pH}=3$ and (3) contaminated soil with chemical solution at $\mathrm{pH}=11$. The results of the XRD test are shown in Fig. 12. It can be observed that the dominant minerals of soil are quartz, albite, calcite, and montmorillonite. It was shown that the soil phase and the ratio of minerals have changed with the addition of acidic and alkaline solutions into the soil. Moreover, it was found that an increase in the percentage of quartz minerals in acidic and alkaline conditions occurred. The percentage of albite mineral was increased with increasing $\mathrm{pH}$ and was decreased in acidic conditions.

\subsection{Scanning electron microscopy (SEM) results}

To better understand the effect of acidic and alkaline solutions on soil structure, the SEM test was performed on three soil samples similar to the XRD test. The SEM images of three soil samples are presented in Fig. 13. It can be seen that the contaminated soil with $\mathrm{pH}=3$, still retained the pore structure with many void spaces. The change in the microstructure of minerals caused weaken the bond between the grains and as a result, the increasing collapse is justified. However, in contaminated soil with chemical solution at $\mathrm{pH}=11$, soil cavities have decreased, which has led to a reduction in soil collapse in alkaline condition.

\section{Discussion}

In this study, the effect of chemical solution at different $\mathrm{pH}$ levels on collapsible loess soil was studied. According to the fact that the soil studied was fine-grained and placed in the CL soil type, the results were almost similar to those of the previous studies. However, this study compared to the previous studies comprehensively investigated the effect of $\mathrm{pH}$ from acidic to alkaline level.

A more detailed look at the tests shows that significant changes in soil conditions occur with the addition of chemical solutions to the collapsible soil. Since the stability of soil structure and the strength of collapsible soil is directly related to particle bonding of the soil, the change in the soil phase and the ratio of minerals has a major impact on the conditions of the collapsible soil. SEM test shows changes in the microstructure of the soil which is visible in both acidic and alkaline conditions. On the other hand, the XRD test shows that the chemical composition of the soil has also changed. Based on the available evidences in SEM and XRD tests, results of the collapse, direct shear and UCS tests can be investigated.

According to the SEM test, cavities of collapsible soil increase in acidic conditions that cause an increase in collapse potential and a decrease in soil strength which is reasonably expected. But the opposite result is observed 


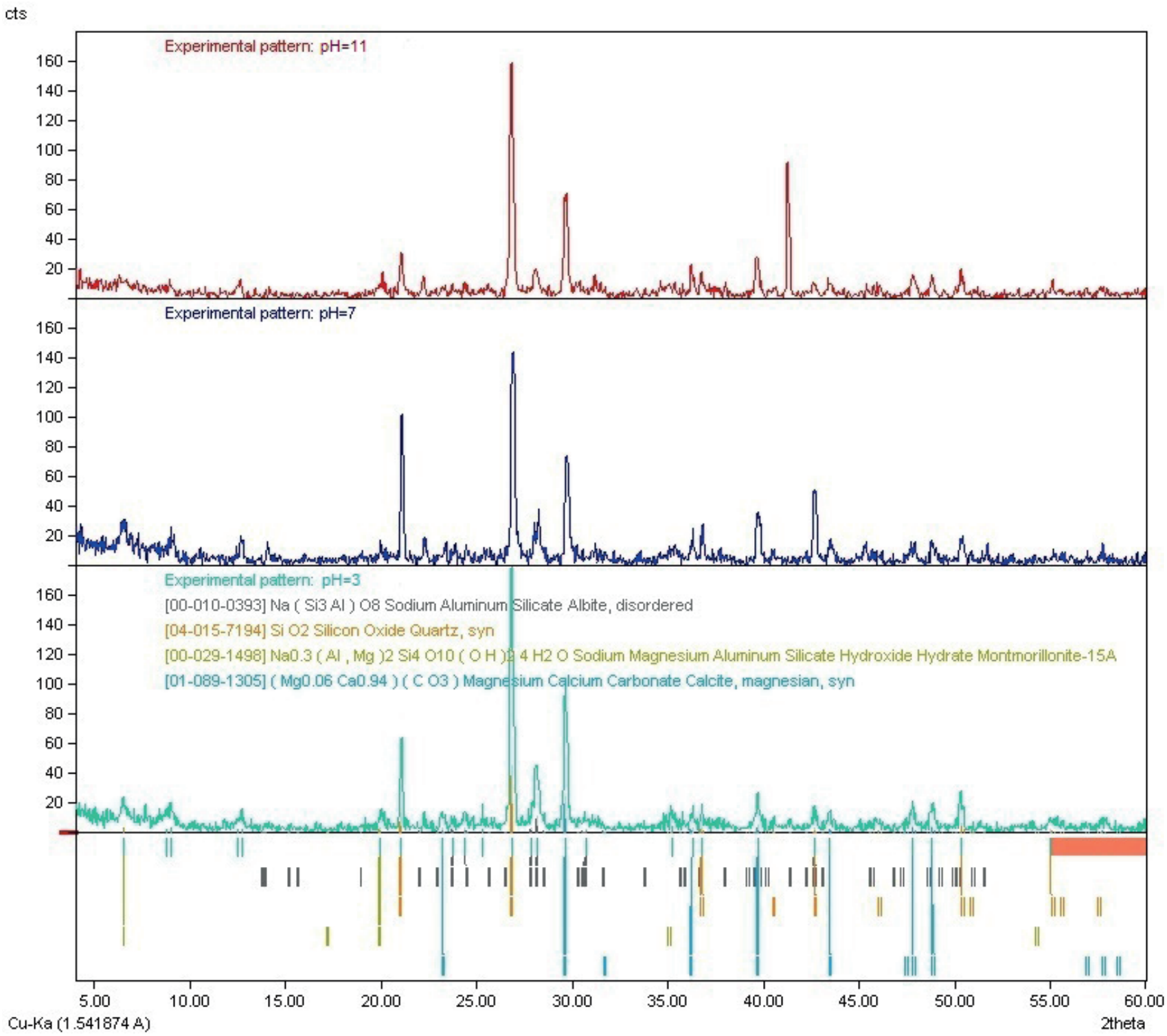

Fig. 12 The results of XRD tests for samples contaminated with chemical solutions at different $\mathrm{pH}$ levels

in the contaminated soil with an alkaline chemical solution, which led to a decrease in collapse potential and an increase in soil strength based on the SEM test.

As it was clearly explained in the sample preparation section, the condition of testing collapse potential and direct shear tests were quite different from the UCS tests. This shows that the behavior of soil may be significantly different according to the method of adding chemical solutions to the soil and one of the reasons for the different results of researchers is related to the condition of sampling.

\section{Conclusions}

In this paper, the effects of chemical solutions with different $\mathrm{pH}$ on the collapse potential, shear strength parameters and unconfined compression of collapsible soils were investigated. The results of collapse tests showed that by decreasing the $\mathrm{pH}$ of the chemical solution from 7 to 3 , the rate of collapse increased by 5.08 percent and with increasing $\mathrm{pH}$ from 7 to 11 , the rate of soil collapse decreased by 2.04 percent that were proved in SEM images. Also, the range of changes in the collapse potential of soil was much higher in acidic conditions compared to alkaline conditions. The results of direct shear test showed that the effective cohesion increased from $14.5 \mathrm{kPa}$ to $35.33 \mathrm{kPa}$ in acidic condition and decreased from $14.5 \mathrm{kPa}$ to $8.16 \mathrm{kPa}$ in alkaline condition. It is also observed that the range of effective cohesion parameters in acidic condition was much higher than alkaline condition. It was also observed that effective internal friction angle of soil decreased by $2.46^{\circ}$ in acidic condition and increased by $3.39^{\circ}$ in 

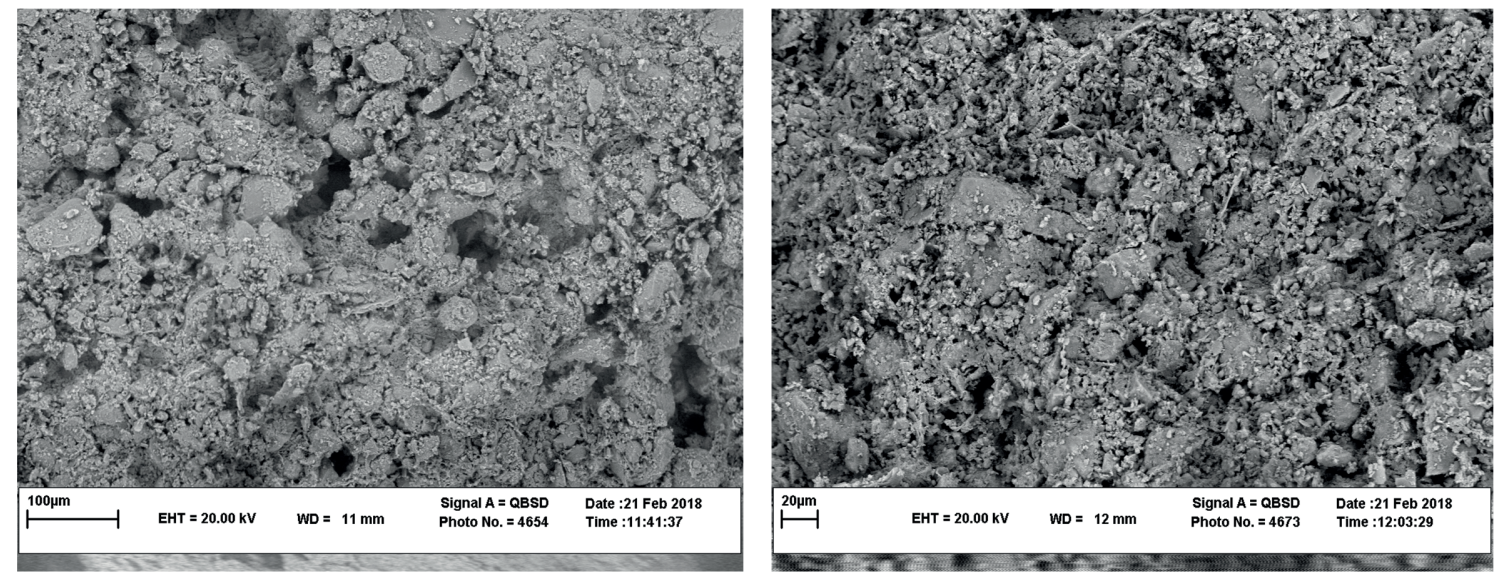

(a)
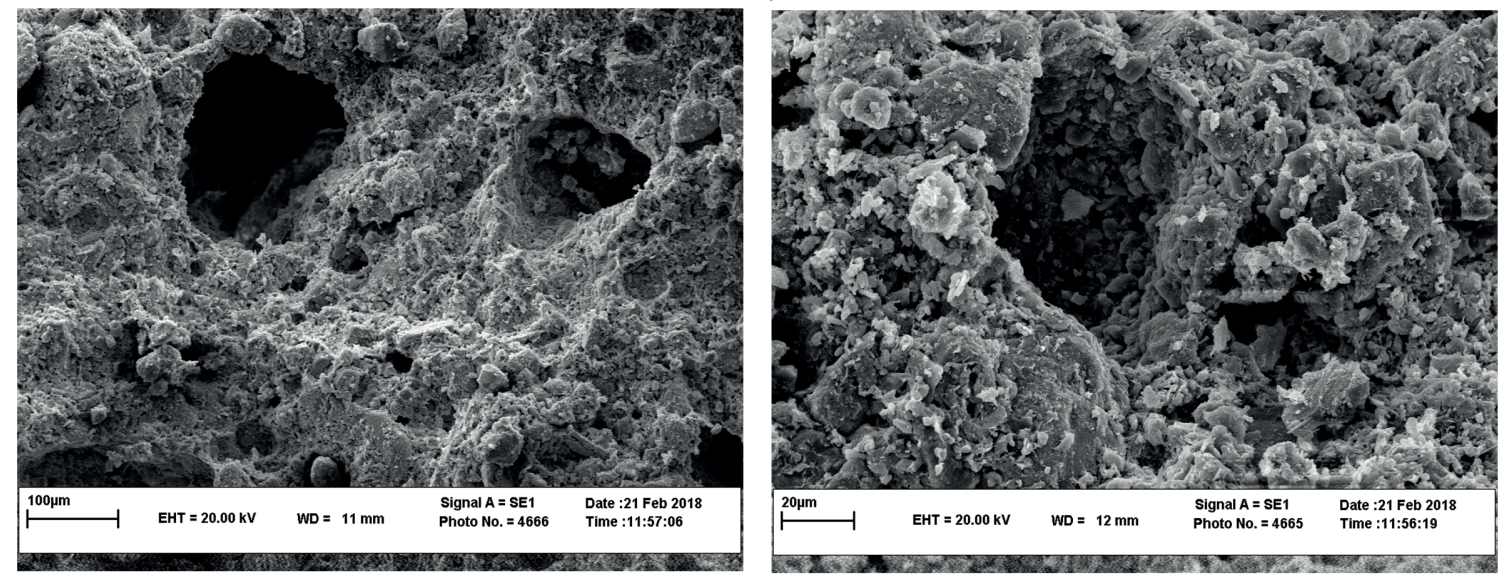

(b)
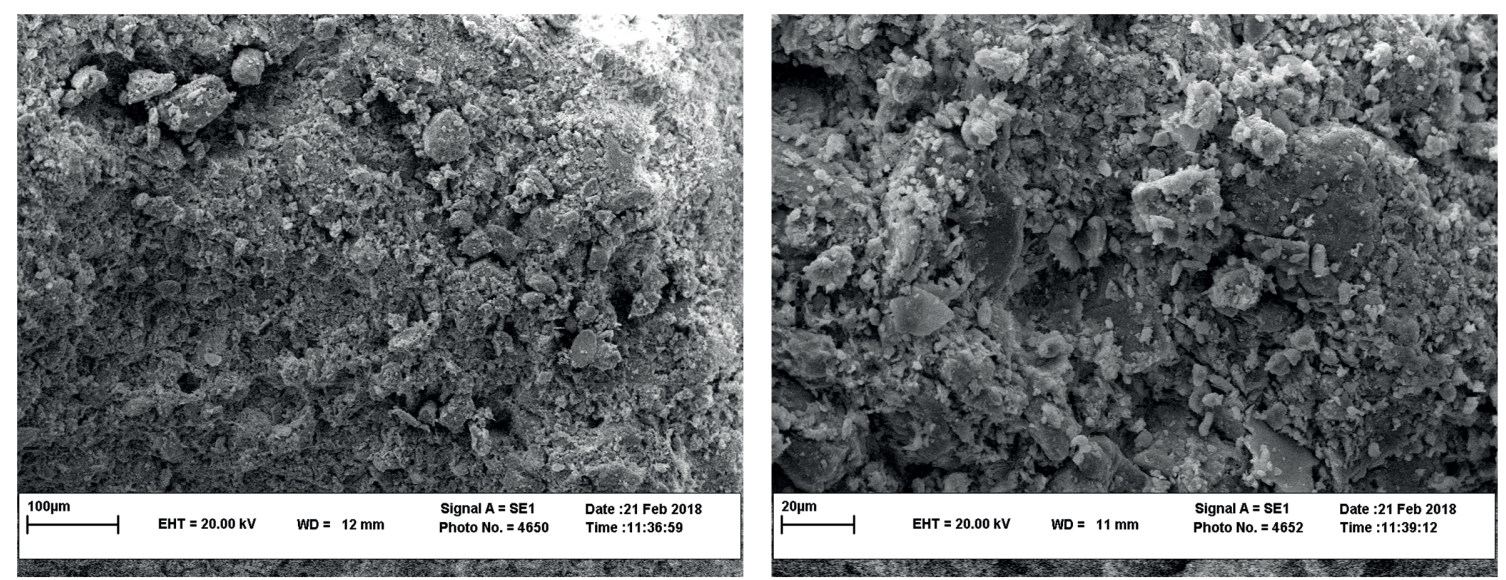

(c)

Fig. 13 The results of SEM tests for remolded loess soils (a) Clean soil (b) Contaminated soil with chemical solution at $\mathrm{pH}=3$ (c) Contaminated soil with chemical solution at $\mathrm{pH}=11$

alkaline condition. The results of unconfined compression test showed that with increasing the acidity and alkalinity in chemical solution, the undrained strength of the soil decreased. Consequently, in the case of acidic contamination, the risk of an increase in collapse potential should be considered. While alkaline pollutants do not only cause any concern for the problem of collapse, but alkaline materials also can be used to some extent to reduce the collapse potential.

\section{Conflict of interest}

The authors declare that they have no conflict of interest. 


\section{References}

[1] Francisca, F. M. "Evaluating the Constrained Modulus and Collapsibility of Loess from Standard Penetration Test", International Journal of Geomechanics, 7(4), pp. 307-310, 2007. https://doi.org/10.1061/(ASCE)1532-3641(2007)7:4(307)

[2] Nouaouria, M. S., Guenfoud, M., Lafifi, B. "Engineering properties of loess in Algeria", Engineering Geology, 99(1-2), pp. 85-90, 2008.

https://doi.org/10.1016/j.enggeo.2008.01.013

[3] Munoz-Castelblanco, J. A., Delage, P., Pereira, J. M., Cui, Y. J. "On-sample water content measurement for a complete local monitoring in triaxial testing of unsaturated soils", Géotechnique, 62(7), pp. 595-604, 2012.

https://doi.org/10.1680/geot.10.P.129

[4] Nokande, S., Khodabandeh, M. A., Hosseini, S. S., Hosseini, S. M. "Collapse Potential of Oil-Contaminated Loessial Soil (Case Study: Golestan, Iran)", Geotechnical and Geological Engineering, 38, pp. 255-264, 2020. https://doi.org/10.1007/s10706-019-01014-9

[5] Daraei, A., Sherwani, A. F. H., Faraj, R. H., Mohammad, S., Kurdo, S., Zare, S., Mahmoodzadeh, A. "Stabilization of problematic soil by utilizing cementitious materials", Innovative Infrastructure Solutions, 4, Article number: 33, 2019.

https://doi.org/10.1007/s41062-019-0220-5

[6] Ng, C. W. W., Sadeghi, H., Hossen, S. K. B., Chiu, C. F., Alonso, E. E., Baghbanrezvan, S. "Water retention and volumetric characteristics of intact and re-compacted loess", Canadian Geotechnical Journal, 53(8), pp. 1258-1269, 2016.

https://doi.org/10.1139/cgj-2015-0364

[7] Yates, K., Fenton, C. H., Bell, D. H. "A review of the geotechnical characteristics of loess and loess-derived soils from Canterbury, South Island, New Zealand", Engineering Geology, 236, pp. 11-21, 2018.

https://doi.org/10.1016/j.enggeo.2017.08.001

[8] Muhs, D. R. "Paleosols and wind-blown sediments: Overview", In: Elias, S. (ed.) Encyclopedia of Quaternary Science, Elsevier Science, London, UK, 2007, pp. 2075-2086.

https://doi.org/10.1016/B0-44-452747-8/00378-1

[9] Gaaver, K. E. "Geotechnical properties of Egyptian collapsible soils", Alexandria Engineering Journal, 51(3), pp. 205-210, 2012. https://doi.org/10.1016/j.aej.2012.05.002

[10] Kaya, A., Fang, H.-Y. "Experimental evidence of reduction in attractive and repulsive forces between clay particles permeated with organic liquids", Canadian Geotechnical Journal, 42(2), pp. 632-640, 2005.

https://doi.org/10.1139/t04-099

[11] Ratnaweera, P., Meegoda, J. "Shear Strength and Stress-Strain behavior of Contaminated Soils", Geotechnical Testing Journal, 29(2), pp. 133-140, 2006.

https://doi.org/10.1520/GTJ12686

[12] Wang, Y.-H., Siu, W.-K. "Structure characteristics and mechanical properties of kaolinite soils. I. Surface charges and structural Characterizations", Canadian Geotechnical Journal, 43(6), 587$600,2006$.

https://doi.org/10.1139/t06-026
[13] Sridharan, A., Hayashi, S., Du, Y.- J. "Discussion of Structure characteristics and mechanical properties of kaolinite soils. I. Surface charges and structural characterizations", Canadian Geotechnical Journal, 44(2), pp. 241-242, 2007.

https://doi.org/10.1139/t06-133

[14] Moavenian, M. H., Yasrobi, S. S. "Volume change behavior of compacted clay due to organic liquids as permeant", Applied Clay Science, 39(1-2), pp. 60-71, 2008.

https://doi.org/10.1016/j.clay.2007.04.009

[15] Tang, X.-W., Kou, N.-Y., Li, Z.-Z., Chen, Y.-M., Tang, Q. "Influence of anionic surfactants on mechanical characteristics of loess", Rock and Soil Mechanics, 32(1), pp. 141-145, 2011. [online] Available at: http://en.cnki.com.cn/Article_en/CJFDTotal-YTLX 201101026.htm

[16] Olgun, M., Yildiz, M. "Influence of acetic acid on structural change and shear strength of clays", Iranian Journal of Science and Technology, Transactions of Civil Engineering, 36(C1), pp. 25-38, 2012.

https://doi.org/10.22099/ijstc.2012.643

[17] Spagnoli, G., Rubinos, D., Stanjek, H., Fernández-Steeger, T., Feinendegen, M., Azzam, R. "Undrained shear strength of clays as modified by $\mathrm{pH}$ variations", Bulletin of Engineering Geology and the Environment, 71, pp. 135-148, 2012.

https://doi.org/10.1007/s10064-011-0372-9

[18] Yang, Y., Wang, G., Xie, S., Tu, X., Huang, X. "Effect of mechanical property of cemented soil under the different $\mathrm{pH}$ value", Applied Clay Science, 79, pp. 19-24, 2013. https://doi.org/10.1016/j.clay.2013.02.014

[19] Rahman, Md. M., Nahar, T. T. "Effect of pH on Shear Strength Behavior of Granular Soil", Global Journal of Researches in Engineering, 15(1), 2015. [online] Available at: https://engineeringresearch.org/index.php/GJRE/article/view/1279

[20] Reddy, H. P., Prasad, C. R. V., Pillai, R. J. "Swelling of Natural Soil Subjected to Acidic and Alkaline Contamination", Periodica Polytechnica Civil Engineering, 61(3), pp. 611-620, 2017 https://doi.org/10.3311/PPci.8185

[21] Li, J.-S., Xue, Q., Wang, P., Liu, L. "Influence of leachate pollution on mechanical properties of compacted clay: A case study on behaviors and mechanisms", Engineering Geology, 167, pp. 128133, 2013.

https://doi.org/10.1016/j.enggeo.2013.10.013

[22] Sunil, B. M., Shrihari, S., Nayak, S. "Shear strength characteristics and chemical characteristics of leachate-contaminated lateritic soil", Engineering Geology, 106(1-2), pp. 20-25, 2009.

https://doi.org/10.1016/j.enggeo.2008.12.011

[23] ASTM "ASTM D5333-03 Standard Test Method for Measurement of Collapse Potential of Soils", ASTM International, West Conshohocken, PA, USA, 2003. http://doi.org/10.1520/D5333-03

[24] ASTM "ASTM D3080/D3080M-11 Standard Test Method for Direct Shear Test of Soils Under Consolidated Drained Conditions", ASTM International, West Conshohocken, PA, USA, 2011.

http://doi.org/10.1520/D3080_D3080M-11 
[25] ASTM "ASTM D2166/D2166M-16, Standard Test Method for Unconfined Compressive Strength of Cohesive Soil, ASTM International", West Conshohocken, PA, USA, 2016. http://doi.org/10.1520/D2166_D2166M-16

[26] Hosseini, A. "Stabilization and Improvement of Collapsible Soils, Using Electrokinetics \& Nanomaterials and Assessment Its Strength Parameters by Unsaturated Oedometer", PhD Thesis, Sharif University of Technology, 2014.

https://doi.org/10.13140/RG.2.2.23851.95526/1
[27] Sivapullaiah, P. V., Prasad, B. G., Allam, M. M. "Effect of Sulfuric Acid on Swelling Behavior of an Expansive Soil", Soil and Sediment Contamination: An International Journal, 18(2), pp. $121-135,2009$

https://doi.org/10.1080/15320380802660289 